\title{
Energy saving and energy efficiency of the Belarusian economy: analysis of concepts and evaluation criteria, proposed approaches to improving the energy efficiency of the housing stock
}

\author{
Q. A. Kamecko, S.V.Izmailovich, Sati Rabih, and A. A. Tivanova \\ Polotsk, State University, Novopolotsk, Belarus
}

\begin{abstract}
The article analyzes the concepts and indicators for assessing energy saving and energy efficiency, which revealed a clear terminological relationship between the studied concepts and the absence of evaluation criteria that characterize important components of energy efficiency by type of economic activity and economic spheres. The most important components of energy efficiency were identified and calculations confirming the importance of the national policy to improve the energy efficiency of the housing stock as the sector with the highest energy saving potential were made. It was confirmed that in order to achieve high indicators of real economic growth, both consistent and constructive measures are needed to create energy facilities of a new formation, as well as to improve existing capacities and facilities, for example, in the form of major repairs of the housing stock.
\end{abstract}

\section{Introduction}

The relevance of energy efficiency issues at various levels of the economy is determined by the specific conditions of any economic system, the peculiarities of the functioning and development of the energy sector, as well as the current trends in the global economy amid global fuel and energy problems and environmental issues.

Under these conditions, the state policy of transition of the Republic of Belarus to the path of innovative resource and energy-saving development, which provides for implementation of the strategy of energy efficiency, energy saving and energy substitution, is absolutely justified and practically non-alternative. This is enshrined in a number of legal acts, including the National Strategy for Sustainable Socio-Economic Development until 2030 [1], the Law of the Republic of Belarus "On Energy Saving" [2] and others.

The priorities for resource- and energy-saving development are selected based on a number of quite obvious arguments formulated in scientists' studies:

- $\quad$ in terms of the GDP energy intensity (purchasing power parity), our country was in the category of countries with inefficient economies;

- $\quad$ electric energy has taken a key place in the material foundation of modern society; 
- heat energy in the required amount is a fundamental condition for a comfortable life of the population;

- $\quad$ sustainable growth of the society's welfare is possible only with a decrease in the growth rate of specific energy consumption;

- the large-scale replacement of non-renewable mineral energy resources with renewable ones, and traditional technologies of the electric and heat energy production with advanced ones, makes it possible to extend the availability of traditional energy resources and reduce man-made pressure on the environment.

Due to the high degree of relevance, the problem of improving energy efficiency has been studied by individual scientists and research teams of Russian scientists such as V.V. Efremov, G.Z. Markman, I.A. Bashmakov, R.F. Araslanov, A.A. Tupikina, A.S. Gorshkov, A.A. Gladkikh and others. [3,4,5,6,7]. The Institute of Oil and Gas of the Russian Academy of Sciences, the Institute for Sustainable Development of the Public Chamber of the Russian Federation, the Center for Environmental Policy of Russia, the Russian Center for Energy Efficiency and other organizations are engaged in the development of the system of indicators and energy efficiency assessment. Problems of sustainable development of the energy sector and energy efficiency in all sectors of the economy, increasing social stability and economic development, as well as issues of state regulation of energy efficiency at the level of the Republic of Belarus are being dealt by National Academy of Sciences of Belarus, the Ministry of Energy, the Ministry of Architecture and Construction, the Ministry of Housing and Communal Services, the Ministry of Industry, the Ministry of Natural Resources and Environmental Protection, the Ministry of Economy, Belarusian State University, Belarus State Economic University.

The results of research conducted by the World Bank, the United Nations Development Programme and other international organizations are of great practical and scientific importance. Researches in the field of energy efficiency of various countries and regions are carried out by leading international organizations such as European Commission, International Energy Agency and others.

A number of scientists such as T.G. Pospelova, N.A. Khaustovich, T.H. Gulbrandsen, L.P. Padalko, V.L. Chervinsky, V.L. Ganja, I.V. Galuzo, I.N. Potapov, V.A. Baidakov[8,9,10,11,12] and others are engaged in the development of theory and methodology, specific methodological tools to ensure energy efficiency in the Belarusian economy.

In addition to domestic sources, the authors also turned to the publications of foreign scientists whose areas of interest are the optimal use of energy resources and energy efficiency analysis $[13,14,15,16]$.

\section{Objects, tasks and stages of the study}

The object of the research is processes and phenomena in the field of energy saving and energy efficiency, their assessing criteria and ways to improve them.

The purpose of the study is to analyze and improve the concepts and indicators for assessing energy saving and energy efficiency, as well as to evaluate the effectiveness of the proposed measures to improve the energy efficiency of the housing stock of the Republic of Belarus within the framework of the national policy of energy efficiency of residential buildings to achieve high indicators of real economic growth.

The objectives of the study are to identify the terminological relationships of the concepts of energy saving and energy efficiency and their constituent elements; to systematize the criteria for assessing energy efficiency at different levels of the economy, types of activities and the constituent elements; to develop an algorithm for implementing an energy efficiency program in the form of heat modernization project for the residential 
sector; to conduct a feasibility study and calculate the economic effect of energy efficiency measures in housing stock.

The stages of the research are theoretical and methodological justification; financial and economic calculations of the proposed activities; formulation of conclusions and recommendations.

In researching the efficient use of energy resources, the terms energy saving and energy efficiency are used to identify them. The authors of the article take the position that energy efficiency and energy saving are different concepts. In the study, they adhere to the point of view that energy saving refers to conservancy of energy or any resource; energy efficiency should be understood as the process of optimal use of energy resources, taking into account at least the economic, environmental and social components in a certain time period.

In scientific publications, "energy saving" is often interpreted as actions or measures aimed at reducing energy waste and energy consumption of technological processes, industrial and household equipment.

According to the EU Energy Efficiency Directive (2012) [17], differentiation of the categories analyzed can be presented as follows: energy efficiency is the ratio of the value of productivity, goods, services and energy to the energy consumed; energy saving is the amount of energy saved, which is determined by measuring and (or) evaluating before and after the implementation of measures to improve efficiency while ensuring the normalization of external conditions that affect energy consumption.

In European countries, the definition given by the Lawrence Berkeley National laboratory (2010) [18] is generally accepted: energy efficiency is "less energy consumption to provide the same services".

In accordance with the Law of the Republic of Belarus No. 239-Z of January 8, 2015 [19], energy saving is an organizational, practical, scientific, informational and other activity of entities in the field of energy saving, aimed at more efficient and rational use of fuel and energy resources.

In the same legislative act, energy efficiency is defined as a characteristic that reflects the ratio of the received effect from the use of fuel and energy resources to the costs of fuel and energy resources produced in order to obtain such an effect; or through indicators that reflect the ratio of the useful effect from the use of energy resources to their expenses produced in order to obtain such an effect, in relation to products, technological processes, legal entities, individual entrepreneurs.

It should be noted that the efficient use of energy resources within the framework of the modern concept of "green" economy should be considered as an achievement of economically justified efficiency of energy resources use (transformative meaning - the result of actions) in conditions of the existing level of technology and technology development and compliance with the requirements to environmental protection.

In order to study and analyze energy efficiency and energy saving, it is necessary to form systems of indicators, which are used for comparison and comparative analysis of data in dynamics and structure. Such a system of indicators makes it possible to compare the assessment result with the maximum possibilities of ensuring energy savings.

The research by Prof. V.P. Samarina presents the following two approaches to energy efficiency measurement. "According to the first approach, only the result or effect is taken as an assessment of energy efficiency" (saving energy resources or reducing energy consumption) [20].Thus, the cost of achieving a result is not taken into account, which in Samarina's opinion, and we fully share this opinion, "cannot be called correct from an economic point of view" [20].

The second approach is to study "the ratio between economic outcomes (output, GDP, etc.) and energy costs (energy consumption, energy production costs, etc.). For example, 
International statistics of the United Nations and the World Bank energy efficiency is considered as a ratio of GDP to energy consumption in oil equivalent units"[20].

In principle, the presented approaches to energy efficiency assessment correspond to the difference in the interpretation of the terms energy saving and energy efficiency, which have been analyzed above.

The global and scientific community on energy efficiency issues has so far developed the following system of indicators, which are presented both at the level of the economy as a whole and at the regional level, as well as at the level of energy efficiency of production complexes and processes. It includes energy intensity of GDP, energy efficiency of GDP, integrated energy efficiency indicator (energy efficiency index), energy intensity of GVA (gross value added).

Next, we will consider the system of energy efficiency indicators in the region using the systematization presented by Y.N. Akulova [21]. It is characterized by determining the energy intensity of GRP (gross regional product), energy intensity of production, energy intensity of organizations, energy intensity of local budgets, profitability of energy efficiency measures (policies), energy-economic level of production in the region, etc.

The analysis of the above works [8-21] by domestic and foreign specialists and scientists allows us to identify two approaches to the formation of indicators and the subsequent study of energy efficiency of production complexes and processes.

The authors of the work identified that the first approach divides energy efficiency indicators into economic (cost), technical and economic (physical), and indicators of the degree of implementation of energy-efficient technologies. Methods that implement this approach, for example, include one of the methods of the World Energy Council [22].

The second approach divides energy efficiency indicators by type of activity: the level of sectoral activities, structural activities (a combination of different activities within the industry) and energy intensity. Examples of methodologies implementing this approach are the Asia Pacific Research Center (2000) [23], the International Energy Agency's indicators project (2009), the French Environment Agency's project ADEME (2010), the Strategy and Energy Efficiency Technical Service of the World Energy Council (2009), and one of the methods of Lawrence Berkeley National Laboratory (2010) [18].

Thus, the most significant and most common in scientific publications indicators of energy efficiency at the macroeconomic and regional levels have been considered, as well as at the level of production complexes and processes in terms of various scientific approaches.

It should be noted that most scientific publications lack indicators that characterize energy efficiency components, which in our opinion is an apparent gap in research. According to the authors, energy efficiency should be characterized through the following components: heat efficiency, electrical efficiency, renewable energy efficiency, etc. In addition, it is most reasonable to consider these indicators in relation to specific activities. This, in turn, is related to the specific activities of business entities at different levels of the national economy.

As foreign and domestic experience shows, in order to achieve high indicators of real growth of the economy, consistent and constructive measures are necessary, aimed not only at creating industrial enterprises of a new formation, but also at improving existing production capacities in various sectors of the economy. In this direction, the national policy in the field of energy efficiency improvement of the housing stock (State Program "Energy Saving") plays an important role. The housing sector has the greatest potential for energy saving.

It should be noted that the housing stock is a specific area of activity with its inherent features. First, it provides the population with residential area. Hence, the second feature is 
a direct impact on the quality of people's lives. In addition, the housing stock requires effective operation and timely maintenance, which, in turn, is also a peculiarity.

The housing stock is one of the largest energy consumers along with other entities of the national economy of Belarus. The reduction of energy consumption by the housing stock has a significant impact on the use of fuel and energy resources for energy production by increasing the energy efficiency of residential property.

Energy efficiency of the housing stock will be determined by improving the quality of energy production and use (primarily electricity and heat). For more detailed consideration, we propose to focus on a component of energy efficiency - heat efficiency of the housing stock.

On the basis of the analysis of the points of view presented in various scientific sources, we have defined the category "heat efficiency of housing stock" as a rational use of heat energy, ensuring the maintenance of micro-climate in the room and the heat balance with the environment with the purpose of reasonable consumption of resources for its production by various methods.

There are two main directions to improve energy efficiency of facilities through the impact on heat energy: improving the efficiency of heat supply systems and reducing heat loss of enclosing structures.

The first direction involves the modernization of engineering networks of the city system and only indirectly concerns the housing stock. It is the reduction of heat loss of enclosing structures (for example, due to thermal modernization) that has a direct impact on the energy consumption of residential property. We propose to consider the economic effect of thermal modernization of the city's housing stock in order to reduce the consumption of heat energy.

\section{Research methods}

During the research, the authors used the following research methods: analysis, synthesis, observation, comparison, inference by analogy, a systematic approach, as well as special methods and techniques of financial and economic analysis.

\section{Results and discussion}

To achieve the purpose of the research, the authors have developed an algorithm for the implementation of the project on thermal modernization of residential property for an urban settlement with a population of 98.452 people (according to the national census of 2019). In previous studies, the authors determined that these measures would allow to save up to $40 \%$ of the heat energy supplied to the entity and, consequently, produced. This, in turn, provides the expected economic effect[24]. Belarus has a system of cross-subsidizing the population's expenses for housing and communal services - a significant part of expenses (about 70\%) is covered by the State from the budget funds. In the near future, the government plans to fully fix the population with the costs for housing and communal services. The implementation of the proposed algorithm will allow to ease burden of payments for the population and to attract additional funds to local and republican budgets.

In general, the project implementation includes two cycles of thermal modernization works. The number of entities involved in the first and second cycles of thermal modernization was determined by the ratio of 1:3. The total term of the project implementation is 20 years. This is determined by the government policy aimed at providing social and economic support to the population. Proceeding from the total duration, the first and second cycles will be completed in 5 and 15 years respectively. The 
project implementation algorithm includes not only direct implementation of modernization cycles, but also other stages ensuring successful implementation of the initiative. It describes fulfillment of the following stages:

1. Search for funding sources for the first project cycle.

2. Evaluation of project effectiveness.

3. Allocation of funds and implementation of the first project cycle.

4. Formation of the source of financing and works of the second cycle of modernization.

Let's look at the phased implementation of the project in more detail.

The main problem that arises right at the start of the project is the identification of funding sources. Based on the presence of cross-subsidization, the authors propose to divide the costs of heat modernization in the ratio of 1:1 between the government and the population. For the population, it is proposed to restructure the cost of housing and communal services under the article "Capital repair" including the cost of heat modernization of housing facilities. The system of organization of the capital repair in the Republic is distributed and does not imply the accumulation of funds allocated by citizens to a particular residential building. These funds are accumulated in the accounts and are constantly in circulation (when they are credited to the account they are sent to settlements with contractors), which ensures the constant implementation of work on capital repairs of the housing stock in the current year according to the schedule of capital repairs approved by local authorities.

Determining the project performance indicators at the initial stage of the proposed algorithm plays a crucial role. When considering the project, a scenario approach was used: pessimistic (saving 10\% of energy), optimistic (saving $40 \%$ of energy) and the most probable (saving $20 \%$ of energy) variant of its implementation were considered. Options are based on determining the need for heat supply to entities, changes in the cost of services, and other parameters. To illustrate the potential effectiveness of the project, an optimistic implementation option is further considered. Based on the calculated data of the study, the payback period of the project (PP) will be 11.98 years. According to the previous research [24] the net present value (NPV) of the project is $1667270 \mathrm{BYN}$, and the annuity rate (IRR) is $33.3 \%$. Since the discount level of $15 \%$ is included in the calculation, we can conclude about the effectiveness of this project.

When the source of funding is formed and the project is recognized as effective, it is possible to proceed to the first project cycle. The estimated data is given in Table 1.

Table 1.Determination of savings from the implementation of the first cycle of the project for thermal modernization of the city according to the optimistic option (considering discounting).

\begin{tabular}{|c|c|c|c|c|c|}
\hline $\begin{array}{c}\text { Year } \\
\text { of } \\
\text { pro } \\
\text { ject } \\
\text { im } \\
\text { ple } \\
- \\
\text { me } \\
\text { nta } \\
- \\
\text { tio } \\
\text { n }\end{array}$ & $\begin{array}{c}\text { Percentageofinsulatedentities, } \\
\%\end{array}$ & $\begin{array}{c}\text { Cost of thermal } \\
\text { modernizati } \\
\text { on, BYN }\end{array}$ & $\begin{array}{c}\text { Thermal } \\
\text { energ } \\
\mathrm{y} \\
\text { savin } \\
\text { g of } \\
\text { new } \\
\text { entiti } \\
\text { es, } \\
\text { Gcal }\end{array}$ & $\begin{array}{c}\text { Project } \\
\text { thermal } \\
\text { energy } \\
\text { saving } \\
\text { for the } \\
\text { year of } \\
\text { implem } \\
\text { ent- } \\
\text { tation, } \\
\text { Gcal }\end{array}$ & $\begin{array}{c}\text { Cost of saved } \\
\text { heat } \\
\text { energy on } \\
\text { the } \\
\text { project } \\
\text { BYN }\end{array}$ \\
\hline $\begin{array}{c}1^{\text {st }} \\
\text { yea } \\
\text { r }\end{array}$ & 5 & 3697826 & 182 & 182 & 617339 \\
\hline
\end{tabular}




\begin{tabular}{|c|c|c|c|c|c|}
\hline $\begin{array}{l}2^{\text {nd }} \\
\text { yea }\end{array}$ & $5(+5)$ & 3215501 & 182 & 364 & 1073633 \\
\hline $\begin{array}{c}\mathrm{r}^{\mathrm{rd}} \\
\text { yea }\end{array}$ & $5(+10)$ & 2796088 & 182 & 546 & 1400391 \\
\hline $\begin{array}{c}{ }^{\mathrm{r}} \\
4^{\text {th }} \\
\text { yea }\end{array}$ & $5(+15)$ & 2431381 & 182 & 728 & 1623642 \\
\hline $\begin{array}{c}\stackrel{r}{5^{\text {th }}} \\
\text { yea }\end{array}$ & $5(+20)$ & 2114244 & 182 & 910 & 1764828 \\
\hline $\begin{array}{c}r \\
\text { Total }\end{array}$ & 25 & 14142443 & $\begin{array}{r}182 \text { each } \\
\text { year }\end{array}$ & 2730 & 6479834 \\
\hline
\end{tabular}

As it can be seen from the calculation, in the first cycle of the project implementation due to reduction of heat supply and, as a result, its production, savings for this purpose will amount to $6,479,834 \mathrm{BYN}$. This is the start-up capital for the implementation of the second cycle of the project.

Having spent the initial capital, the second cycle goes into the stage of self-financing. This is possible by redistributing the saved funds from energy production to further thermal modernization.

The calculation for the second cycle is shown in Table 2. The calculation is based on an optimistic scenario, as for the first cycle.

Table 2. Calculation of the duration of the second cycle of the project for thermal modernization of the city.

\begin{tabular}{|c|c|c|c|c|c|c|}
\hline $\begin{array}{c}\text { Year of } \\
\text { project } \\
\text { imple- } \\
\text { mentation } \\
\left(2^{\text {nd }} \text { cycle }\right)\end{array}$ & $\begin{array}{c}\text { Percen- } \\
\text { tage of } \\
\text { insulate } \\
\mathrm{d} \\
\text { entities, } \\
\%\end{array}$ & $\begin{array}{l}\text { Project } \\
\text { thermal } \\
\text { energy } \\
\text { saving for } \\
\text { the year of } \\
\text { implement } \\
\text {-tation, } \\
\text { Gcal }\end{array}$ & $\begin{array}{l}\text { Cost of } \\
\text { thermal } \\
\text { moderniza- } \\
\text { tion*, } \\
\text { BYN }\end{array}$ & $\begin{array}{c}\text { Cost of } \\
\text { moderniza- } \\
\text { tion **, } \\
\text { BYN }\end{array}$ & $\begin{array}{l}\text { Cost of } \\
\text { saved heat } \\
\text { energy on } \\
\text { the } \\
\text { project**, } \\
\text { BYN }\end{array}$ & $\begin{array}{l}\text { The rest of the } \\
\text { money for the } \\
\text { moderniza-tion of } \\
\text { the next cycle**, } \\
\text { BYN } \\
\text { prior to } \\
\text { implementation } \\
\text { after implementation }\end{array}$ \\
\hline $1^{\mathrm{st}}\left(6^{\mathrm{th} *}\right)$ & $5(+25)$ & 1092 & 4252500 & 1838473 & 1841560 & 5632371 \\
\hline year & & & & & & 5635458 \\
\hline $2^{\text {nd }}\left(7^{\text {th } *}\right)$ & $5(+30)$ & 1274 & 4252500 & 1598672 & 1868249 & \\
\hline year & & & & & & 5905035 \\
\hline $3^{\text {rd }}\left(8^{\text {th }}\right)$ & $5(+35)$ & 1664 & 4252500 & 1390150 & 1856645 & \\
\hline year & & & & & & 5866993 \\
\hline $4^{\text {th }}\left(9^{\text {th } *}\right)$ & $5(+40)$ & 1856 & 4252500 & 1208826 & 1816283 & \\
\hline year & & & & & & 6371530 \\
\hline $5^{\text {th }}\left(10^{\text {th } *}\right)$ & $5(+45)$ & 2048 & 4252500 & 1051153 & 1754863 & \\
\hline year & & & & & & 7075240 \\
\hline $6^{\text {th }}\left(11^{\text {th } *}\right)$ & $5(+50)$ & 2240 & 4252500 & 914046 & 1678565 & \\
\hline year & & & & & & 7839759 \\
\hline $7^{\text {th }}\left(12^{\text {th } *}\right)$ & $5(+55)$ & 2432 & 4252500 & 794823 & 1592314 & \\
\hline year & & & & & & 8637250 \\
\hline
\end{tabular}




\begin{tabular}{|c|c|c|c|c|c|c|}
\hline $\begin{array}{c}8^{\text {th }}\left(13^{\text {th } *}\right) \\
\text { year }\end{array}$ & $5(+60)$ & 2624 & 4252500 & 691150 & 1500006 & 9446106 \\
\hline $\begin{array}{c}9^{\text {th }}\left(14^{\text {th } *}\right) \\
\text { year }\end{array}$ & $5(+65)$ & 2816 & 4252500 & 601000 & 1404688 & 10249794 \\
\hline $\begin{array}{c}10^{\text {th }}\left(15^{\text {th } *}\right) \\
\text { year }\end{array}$ & $5(+70)$ & 3008 & 4252500 & 522609 & 1308716 & 11035901 \\
\hline $\begin{array}{c}11^{\text {th }}\left(16^{\text {th } *}\right) \\
\text { year }\end{array}$ & $5(+75)$ & 3200 & 4252500 & 454442 & 1213881 & 11795340 \\
\hline $\begin{array}{c}12^{\text {th }}\left(17^{\text {th } *}\right) \\
\text { year }\end{array}$ & $5(+80)$ & 3392 & 4252500 & 395167 & 1121521 & 12521694 \\
\hline $\begin{array}{c}13^{\text {th }}\left(18^{\text {th } *}\right) \\
\text { year }\end{array}$ & $5(+85)$ & 3584 & 4252500 & 343624 & 1032602 & 13210672 \\
\hline $\begin{array}{c}14^{\text {th }}\left(19^{\text {th } *}\right) \\
\text { year }\end{array}$ & $5(+90)$ & 3776 & 4252500 & 298803 & 947799 & 13859668 \\
\hline $\begin{array}{c}15^{\text {th }}\left(20^{\text {th } *}\right) \\
\text { year }\end{array}$ & $5(+95)$ & 3968 & 4252500 & 259859 & 867551 & 14467360 \\
\hline
\end{tabular}

Note - * - year from the start of the project (reason for choosing a discount factor)

** - the calculation is made considering the discount factor

Thus, the subsequent income, which will bring a reduction in heat consumption, will be $7,099,400$ rubles annually (excluding the growth in the cost of residential heating services). The income, that will be received after the proposed project is completed, will go to the state budget and over time will cover all expenses of the State that it bears during the implementation of the first project cycle of the project.

In terms of energy efficiency of the economy of the Republic of Belarus, the implementation of the proposed project will lead to a significant economic effect calculated by the authors per capita of the settlement (about 150 rubles), which in terms of the total number of residents of Belarus will be 1,374,399,200 rubles.

\section{Conclusions}

Thus, the authors of the publication have analyzed the concepts and indicators for assessing energy saving and energy efficiency, which revealed a clear terminological relationship and absence of evaluation criteria that characterize important components of energy efficiency by type of economic activity and economic sphere. This made it possible to identify the most important components of energy efficiency and perform calculations confirming the importance of the national policy to improve energy efficiency of the housing stock as a sector with the highest energy saving potential. It is confirmed that in order to achieve high indicators of real economic growth, both consistent and constructive measures to create energy facilities of new formation and improvement of existing capacities and facilities (for example, in the form of thermal modernization of the housing stock) are needed. Improving the efficiency of work on the project of thermal modernization of the city housing stock proposed by the authors to reduce heat consumption under the state program "Energy Saving" is possible due to a number of the following factors: application of quality 
management systems, motivation of employees, search for rational ways of financing, which will reduce the project implementation time.

It should be noted that the approaches proposed by the authors to increase energy efficiency are not the only possible in the national economy. However, a significant economic effect of the measures proposed by the authors is evident at both the micro and macro levels: energy saving in the domestic market may increase energy exports; energy savings will reduce budget expenditures. In this regard, the proposed project takes into account the environmental component in the form of a reduction in the anthropogenic impact on the environment due to a reduction in heat supply from residential premises into the atmosphere, as well as the social component in the form of saving money by households for heat energy under conditions of continuing growth of electricity and heat tariffs.

\section{References}

1. "On approval of the Concept of national security of the Republic of Belarus" as amended. and add. dated January 24, 2014 No. 49. Decree of the President of the Republic of Belarus of November 9, 2010 N575

2. "On Energy Saving". Law of the Republic of Belarus on January 8, 2015 No. 239-Z

3. V. V. Efremov "Energy saving" and "energy efficiency": clarification of concepts, the system of balanced indicators e "energy efficiency". Bulletin of the Tomsk Polytechnic University, 4, 146-148 (2007)

4. I. A. Bashmakov Energy efficiency: from rhetoric to action.

5. A. F. Araslanov Formation of the mechanism of energy efficiency management of socio economic systems of the region.

6. A. A. Tupikina Energy saving and increasing energy efficiency: a history of concepts. Business. Education. Right. Bulletin of the Volgograd Institute of Business, 2, 90-95 (2014)

7. A. S. Gorshkov, A. A. Gladkikh Measures to improve energy efficiency in construction. Construction sciences: building telophysics and energy saving, 3, 246250 (2010)

8. T. G. Pospelova Fundamentals of energy saving, 353 (Minsk: UP "Technoprint", 2000)

9. N. A. Khaustovich Energy efficiency as an important condition for sustainable development of the country's economy. Belarusian Economic Journal, 3, 15-23 (2006)

10. T. Kh. Gulbrandsen Energy efficiency and energy management: study guide, 240 (Minsk: BGATU, 2010)

11. V. L. Ganzha Fundamentals of efficient use of energy resources: theory and practice of energy saving, 451 (Minsk: Belarusian. Science, 2007)

12. I. V. Galuzo, I. N. Potapov, I. N. Baydakov Experimental elective course "Fundamentals of Energy Efficiency" for schoolchildren. Energy Efficiency, 8, 24 (2005)

13. A. H. Rosenfeld The Art of Energy Efficiency: Protecting the Environment with Better Technology. Annual Review of Energy and Environment, 24, 33-82 (1999)

14. A. H. Rosenfeld Real Prospects for Energy Efficiency in the United States. America's Energy Future Panel on Energy Efficiency Technologies; National Academy of Sciences, 203 (Academy of Engineering; The National Academies Press, 2009)

15. R. Haas Energy efficiency indicators in the residential sector. Energy Policy, 25(7-9), 789-802 (1997) 
16. T. R. Lakshmanan, S. Ratick Integrated Models for Economic-Energy-Environmental Impact Analysis. Economic-Environmental-Energy Interactions: Modeling and Policy Analysis, 7-39 (Springer Netherlands, 1980)

17. Energy Efficiency Directive. Directive 2012/27. EU of the European Parliament and of the Council of 25 October 2012, 88, (Brussels, 2012)

18. E. Worrell, M. Neelis, L. Price, C. Galitsky, N. Zhou World Best Practice Energy Intensity Values for Selected Industrial Sectors. (Berkeley CA, Lawrence Berkeley National Laboratory, 2008)

19. "On energy saving and on increasing energy efficiency and on amendments to certain legislative acts of the Russian Federation". Law of the Russian Federation No. 261-FZ of 23.11.2009 (revised on 13.07.2015)

20. V. P. Samarina Assessment of energy efficiency of the Russian economy in comparison with other regions of the world and directions of its improvement. ANI: Economics and Management, 5(3(16)), 178-182 (2016)

21. Ya. N. Akulova The system of indicators for assessing energy efficiency as a factor of economic growth of the regional economy. Vestnik OSU, 4(165), 33-38 (2014)

22. Energy Efficiency: A Recipe for Success. WorldEnergyCouncil, (2010)

23. Energy Efficiency Indicators: A study of energy efficiency indicators for industry in APEC Economies. Asia Pacific Energy Research Centre, (2000).

24. O. A. Kamecko Features of financing of measures to increase energy efficiency of the city housing. Master's dissertation. Ministry of Education of the Republic of Belarus, Polotsk State University, 81 p. (Novopolotsk: PSU, 2018) 